\title{
Agronomic performance of Blackberry cultivars in Lapa-PR
}

\author{
Camila Pereira Croge ${ }^{1}$, Francine Lorena $\mathrm{Cuquel}^{2}$, Luis Antonio Biasi ${ }^{3}$, \\ Claudine de Bona ${ }^{4}$, Paula Toshimi Matumoto Pintro ${ }^{5}$
}

\begin{abstract}
Phenological studies with blackberry cultivars and the physical, chemical and sensory characterization of fruits are necessary to select the best cultivar adapted to local conditions and for the correct destination of fruits. The objective of this work was to evaluate the phenological stages of different blackberry cultivars, as well as to determine the quality of fruits, focusing on the recommendation of cultivars that are more adapted to local climate conditions. Moreover, the aim was to indicate the best destination of fruits produced, for either fresh consumption or as raw material for processing. The results indicated that the cultivars studied have adequate conditions for the expression of their productive potential, being Tupy cultivar the most productive. Fruits of Tupy, Guarani and Cherokee cultivars presented dual aptitude, which means they can be consumed fresh or or as raw material for processing, whereas those of Xavante cultivar are suitable only for processing.
\end{abstract}

Index terms: Rubus, small fruits, phenology, sensory analysis.

\section{Desempenho agronômico de cultivares de Amoreira-Preta na Lapa-PR}

Corresponding author: camilacroge@epagri.sc.gov.br

Received: August 31, 2018 Accepted: February 07, 2019

Copyright: All the contents of this journal, except where otherwise noted, is licensed under a Creative Commons Attribution License.
Resumo - Estudos fenológicos com cultivares de amoreira-preta e a caracterização física, química e sensorial dos seus frutos são necessários para a escolha da cultivar mais adaptada às condições locais e para a destinação correta das frutas. Assim, objetivou-se, com este trabalho, avaliar a fenologia de diferentes cultivares de amoreira-preta, bem como determinar a qualidade de seus frutos com foco na recomendação de cultivares que sejam mais adaptadas ao clima local. Além disso, buscou-se indicar qual a melhor destinação dos frutos produzidos, seja para consumo in natura, seja para matéria-prima na industrialização. Os resultados indicam que as cultivares estudadas tiveram condições adequadas para a expressão de seu potencial produtivo, sendo a cultivar Tupy a mais produtiva. Os frutos das cultivares Tupy, Guarani e Cherokee apresentaram dupla aptidão, ou seja, podem ser consumidos in natura ou destinados à industrialização, já os da cultivar Xavante são adequados apenas para o processamento na indústria de alimentos.

Termos para indexação: Rubus, pequenas frutas, fenologia, análise sensorial.

\footnotetext{
${ }^{1}$ Agronomist, M.Sc. Doctoral student in plant production, Federal University of Parana. Curitiba - PR, Brazil . E-mail: camilacroge@epagri. sc.gov.br (ORCID 0000-0003-0485-6183)

${ }^{2}$ Agronomist, D.Sc. Researcher, Professor in the Department of Agronomy, Federal University of Parana. Curitiba - PR, Brazil. E-mail: flcuquel@ufpr.br(ORCID 0000-0002-3026-2058)

${ }^{3}$ Agronomist, D.Sc. Researcher, Professor in the Department of Agronomy, Federal University of Parana. Curitiba - PR, Brazil. E-mail: biasiufpr@gmail.com ${ }^{\text {(ORCID 0000-0002-3479-8925) }}$

${ }^{4}$ Agronomist, D.Sc. Researcher in Institute Agronomic of Parana. Curitiba - PR, Brazil. E-mail: debona@iapar.br

${ }^{5}$ Agronomist, D.Sc. Researcher, Professor in the Department of Agronomy, State University of Maringa, UEM. Maringá - PR, Brazil. E-mail:

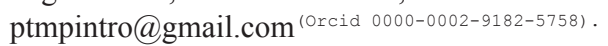




\section{Introduction}

Among fruit crops of temperate climate, blackberry has aroused the interest of producers due to its high aggregate economic value and plant rusticity. In addition, consumer demand is increasing due to the nutraceutical quality inherent of blackberry fruits (STRIK et al., 2008). It is estimated that there are approximately 20 thousand ha cultivated around the world. In South America, the blackberry area is greater than 2500 ha, and there is potential for cultivation expansion (PIO and GONÇALVES, 2014).

Blackberry allows rapid economic return, since plants, if well adapted, can reach high yields in the first productive cycle. Fresh fruits are delicate, but can be destined to industrial processing, since products are of easy commercialization due to their peculiar flavor and nutritional appeal (PEREIRA et al., 2015; SOUZA et al., 2015).

Despite its cultivation characteristics, the planting of more than one cultivar is advisable, because it is possible to reduce the risk of losses and also to allow production scheduling, beneficial for diluting labor with harvest and allowing the entry entrance of fruits on the market. However, before choosing the cultivar, it is important to carry out studies to provide information to determine which cultivars are most adapted to local conditions, the periods of production concentration and the production and commercialization potential of fruits produced (SILVA et al., 2006; ZIELINSKI et al., 2015; CROGE et al., 2016).

In this scenario, the aim of this work was to evaluate the phenological performance of blackberry cultivars, as well as to determine the quality of fruits, focusing on the recommendation of cultivars that are better adapted to local climate conditions and that can be used for planting. In addition, it was sought to indicate the best destination of fruits produced for either fresh consumption or as raw material for processing.

\section{Material and methods}

Blackberry cultivars studied were Tupy, Guarani, Xavante and Cherokee, in the municipality of Lapa-PR, coordinates $25^{\circ} 47^{\prime} \mathrm{S}, 49^{\circ} 46^{\prime} \mathrm{W}$ and 910 masl. Seedlings were planted in 2011, spaced by $1.0 \times 4.0 \mathrm{~m}$ and the training system was vertical shoot position with three double rows of wires open in $\mathrm{V}$ shape. The climate is temperate with mild summer (Cfb) according to Köppen's climatic classification. Cultivation, fertilization and irrigation followed the same pattern for all cultivars and were performed according to results of soil analysis and technical recommendations for the crop (ANTUNES and RASEIRA, 2004; ANTUNES and HOFFMANN, 2012).

The experimental design was randomized block with four treatments (Tupy, Guarani, Xavante and Cherokee cultivars), four replicates and six plants per plot and four taken as useful.

Soil analysis, performed before planting, showed the following nutrient contents: $\mathrm{P}=20.4 \mathrm{mg} \cdot \mathrm{dm}^{-3}, \mathrm{C}=$ $22.2 \mathrm{mg} . \mathrm{dm}^{-3}, \mathrm{Al}=0 \mathrm{cmol} \cdot \mathrm{dm}^{-3} ; \mathrm{H}+\mathrm{Al}=4,3 \mathrm{cmol} \cdot \mathrm{dm}^{-3}$, $\mathrm{Ca}=10.0 \mathrm{cmol} \mathrm{dm}^{-3}, \mathrm{Mg}=3.9 \mathrm{cmol} . \mathrm{dm}^{-3}, \mathrm{~K}=0.3 \mathrm{cmol}$. $\mathrm{dm}^{-3}, \mathrm{SB}=14.2 \mathrm{cmol} \cdot \mathrm{dm}^{-3}, \mathrm{CTC}=18.5 \mathrm{cmol} \cdot \mathrm{dm}^{-3}, \mathrm{~V}=$ $77.0 \%$; and, $\mathrm{pH}=5.6$.

Plants were submitted to weekly visual evaluation from September to December in the 2012/13 and 2013/14 cycles. Phenological evaluations were carried out according to the stages of bud and fruit development (ANTUNES, 2000), at the beginning of flowering (more than $5 \%$ of open flowers), end of flowering ( $90 \%$ of open flowers), beginning and end of harvest. The phenological evaluations were descriptive only.

Fruits were harvested when they reached the full maturation stage, that is, when the epidermis reached bright black color (ANTUNES and HOFFMANN, 2012). The average production per plant (kg per plant) and the estimated productivity per hectare $\left(\mathrm{t} \mathrm{ha}^{-1}\right)$ were determined on the basis of plant density per hectare and fresh fruit mass.

For the physical and chemical characterization of fruits, the following variables were analyzed: fresh mass (g); equatorial and longitudinal diameter ( $\mathrm{mm})$; color of fruit epidermis; firmness; $\mathrm{pH}$; titratable total acidity (TA); and total soluble solids content (TSS). The experimental design was completely randomized, with four treatments (Tupy, Guarani, Xavante and Cherokee cultivars), four replicates per treatment and 25 fruits per plot.

Fruits were weighed to obtain fresh mass. The equatorial and longitudinal diameter was measured with a caliper rule.

Fruit color was measured using a colorimeter, and differences among samples were evaluated, as well as differences in hue and luminosity. The parameters used were $L^{*}, a^{*}$ and $b^{*}$, and hue was determined from the ratio between $b^{*}$ and $a^{*}$. The total color difference was determined using the following equation:

Total color difference $(\Delta \mathrm{E})=\left(\Delta \mathrm{L}^{2}+\Delta \mathrm{a}^{2}+\Delta \mathrm{b}^{2}\right)^{1 / 2}$

Firmness was measured with the aid of texturometer using a cylindrical probe of $36 \mathrm{~mm}$ diameter with compression of $40 \%$ of its height and velocity of $1.5 \mathrm{~mm}$ $\mathrm{s}^{-1}$, as described by Oliveira et al. (2013).

$\mathrm{pH}$ was evaluated with a $\mathrm{pH}$ meter and the electrode was directly inserted into the blackberry fruit juice (INSTITUTO ADOLF LUTZ, 2005).

TA was evaluated by titration according to methodology described by Reyes-Carmona (2005), in which a known volume of blackberry juice was titrated with $0.1 \mathrm{~N} \mathrm{NaOH}$ until $\mathrm{pH}$ reached 8.2. The $\mathrm{NaOH}$ volume used was required to calculate TA, which is expressed as citric acid percentage. 
TSS content was measured in ${ }^{\circ}$ Brix, with direct reading through the addition of a drop of fruit juice on the prism of the refractometer apparatus (INSTITUTO ADOLF LUTZ, 2005).

For the acceptability test, the research project was submitted to evaluation and approval by the Ethics Committee for Research with Humans, Department of Health Sciences, Federal University of Paraná, and was approved by CEP / SD-PB No. 376,500. Fruits were harvested in November 2013 and sanitized for presentation to judges. The evaluation consisted of 120 untrained participants. Analysis was performed according to concepts of terminology related to sensory properties of ABNT standards (1993).

For each attribute (appearance, aroma, texture, taste and overall impression), judges were previously instructed to assign a score ranging from 1 (I highly disliked) to 9 (liked very much). With results, the acceptability index (AI) for each cultivar was calculated from the equation:

$$
\mathrm{AI}=(\mathrm{A} * 100) / \mathrm{B}
$$

where, $\mathrm{A}$ is the average score obtained for the product and $\mathrm{B}$ is the maximum score of the scale for product evaluation. For AI values $\geq 70 \%$, the product is considered of good acceptance (DUTCOSKY, 2007).

Data were submitted to analysis of variance (ANOVA), and when significant, means were compared by the Tukey test with $p \leq 0.05$.

\section{Results and discussion}

It was observed that in the study area, rainfall distribution over the months was uneven in the 2012/13 and 2013/14 cycles (FIGURE 1). Since it is a small plant with superficial root, blackberry needs regular water availability (ANTUNES and RASEIRA, 2004). Thus, in order to provide regular water distribution to plants, irrigation was necessary in periods of lower water availability in the soil, which were clearly identified as the months of March, May, August, September and November in 2012/13 and January, April, August and December in 2013/14. From September on, blackberries began a new growth cycle and lack of water in this period can become a limiting factor for productivity. Irrigation provided enough water for the culture in the study site, mainly in the period of greatest water requirement, at the time of fruit formation and maturation (ANTUNES and RASEIRA, 2004; CROGE et al., 2016).

However, excess water in the harvest stage may compromise fruit quality (CURI et al., 2015). In Lapa-PR, harvest started in the first half of November and lasted until the beginning of January (FIGURE 2). No excessive rainfall was observed in any of the crop cycles, and harvest was not affected by excess water (FIGURE 1).
There were variations in relation to flowering and harvest times between cultivars and cycles (FIGURE 2). This variation is a function of the genetic characteristics of each cultivar in response to climatic phenomena, such as temperature, which directly interferes with plant budding and flowering (ANTUNES et al., 2010).

Flowering period was longer for all cultivars in the 2013/14 cycle because this year was colder, and Xavante cultivar presented the longest period compared to the other cultivars (FIGURE 2). In 2013, temperature during the flowering was lower than in 2012. The average temperatures in September and October 2013 were $15.9^{\circ} \mathrm{C}$ and $18.0^{\circ} \mathrm{C}$, respectively, and in the same months of 2012 , temperatures were $20.7^{\circ} \mathrm{C}$ and $22.4^{\circ} \mathrm{C}$ (FIGURE 1). Despite the prolongation of the flowering period in the 2013/2014 cycle, the occurrence of different phenological stages inside the plant was not observed, since between flowering and harvest, there was a period of at least 10 days of difference, which indicates that the winter cold was sufficient for the breaking of bud dormancy (ANTUNES and HOFFMANN, 2012). Chilling hours below $7.2^{\circ} \mathrm{C}$ accumulated from May to August were 114 in 2012 and 248 in 2013 (SIMEPAR 2012 and 2013).

The shortest flowering period was observed for Cherokee cultivar in 2012/13. Croge et al. (2016) studying the same cultivars in subtropical mesothermal climate, observed that 'Cherokee' cultivar presented the shortest flowering period when compared to the other cultivars. CURI et al. (2015) observed no differences in the flowering period of Tupy, Guarani, Xavante and Cherokee cultivars in altitude tropical climate.

Flowering peaks in both productive cycles only coincided for Tupy cultivar, and 2013/14 provided an advance on the flowering peaks of Xavante and Guarani cultivars and a delay for the Cherokee cultivar. This indicates that the winter cold needed was reached faster for 'Xavante' and 'Guarani' cultivars in 2013/14, which have lower cold requirement when compared to 'Cherokee' cultivar. Tupy, Guarani and Xavante cultivars have low chilling requirement (200 to 300 hours) and Cherokee cultivar have medium to high chilling requirement (400 to 600 hours) (POLLING, 1997; PEREIRA et al., 2014).

Similarities in harvest duration were observed. However, the beginning of the 2013/14 harvest was advanced by approximately one week for Tupy, Guarani and Xavante cultivars. This was probably due to the occurrence of lower temperatures in the winter of the 2013/14 cycle. Moreover, for 'Tupy' cultivar in this same cycle, there was early maturation of fruits within the period between the end of flowering and the beginning of harvest smaller than in the other cultivars. Segantini et al. (2014) observed that the higher the number of cold hours, the shorter the blackberry cycle, and the shorter the blackberry reaches harvest, which probably caused the harvest in Lapa-PR to be anticipated in the 2013/14 cycle. 
In the 2012/13 cycle, there was synchrony in the harvest period of cultivars. In 2013/14, there was synchrony, except for 'Cherokee' cultivar, which presented shorter duration of this phase. However, the desirable production scheduling was not possible. On the other hand, Campagnolo and Pio (2012a) were able to start harvesting Tupy cultivar on 09-12 in 2009/10 and on 1028 in 2010/11, showing that there may be are variations in the productive cycle due to climatic variations, which affect the duration of the blackberry phenological phases and, consequently, the harvest season (CURI et al., 2015).

Table 1 shows the productive performance of blackberry cultivars, in which the highest production, yields and fresh fruit mass were presented by Tupy cultivar, regardless of production cycle. According to Antunes et al. (2010), the productivity of Tupy cultivar in the region of Pelotas-RS was of $5.2 \mathrm{tha}^{-1}$, when grown in an agroecological system. Campagnolo and Pio (2012b) reported that the same cultivar can reach values up to $10.6 \mathrm{tha}^{-1}$. The superiority of productivity values in the present study may be related to water supplementation with irrigation over the cycles.

The lowest production and productivity were observed for Guarani cultivar in the first productive cycle and for 'Cherokee' in the second cycle. Moreover, 'Guarani' cultivar in 2013/14 reached $21.2 \mathrm{t} \mathrm{ha}^{-1}$ even though it had lighter fruits compared to the other cultivars, indicating that the highest number of fruits harvested was from 'Guarani' cultivar in the same year. Campagnolo and Pio (2012b) observed production of $15.1 \mathrm{t} \mathrm{ha}^{-1}$ of 'Guarani' cultivar under humid subtropical climate, which indicates that the climate in the study site is suitable for the production of this cultivar. According to ANTUNES et al. (2014), blackberry productivity can reach up to 25 t ha ${ }^{-1}$ year ${ }^{-1}$ with adequate conditions and handling, and, on average, productions from 10 to $16 \mathrm{t} \mathrm{ha}^{-1}$ year ${ }^{-1}$ have been observed.

The lowest fruit masses were found for Guarani and Cherokee cultivars. Croge et al. (2016) verified, in mesothermic subtropical climate without irrigation, relatively lower masses for 'Tupy' (7.9 g), 'Guarani' (4.1 $\mathrm{g})$, 'Xavante' ( $4.7 \mathrm{~g})$ and 'Cherokee' ( $4.0 \mathrm{~g})$ cultivars, which indicates that climate and irrigation interfere in fruit quality, which may have been the differential in the mass of blackberry fruits in Lapa-PR.

The largest fruit size was obtained for Tupy cultivar (FIGURA 3), which justifies the highest mass detected for the fruits of this cultivar. Smaller fruits were observed for Guarani and Cherokee cultivars. Fruit diameters observed in this work were greater than those observed by Campagnolo and Pio (2012a) and Croge et al. (2016), who evaluated the same cultivars.

Table 2 shows color and firmness data of the 2013/14 cycle for the different cultivars studied. In relation to firmness, firmer fruits were observed for
Guarani cultivar and the lowest firmness was observed for 'Xavante' cultivar. Guedes et al. (2013) found average firmness of $0.44 \mathrm{~N}$ for ten cultivars, with 'Ebano' and 'Cherokee' presenting the highest firmness values $(0.76$ and 0.70 respectively). Firmness is an important feature to indicate the shelf life of fruits and, due to the fact that blackberries are delicate fruits, fruits with greater firmness are preferred.

For $\Delta \mathrm{E}$, which indicates total color, no statically significant differences were observed among cultivars (TABLE 2). On the other hand, Croge et al. (2016) found significant variations in this parameter for blackberries cultivated in subtropical climate. $\Delta \mathrm{E}$ is calculated based on parameters $\mathrm{L}^{*}, \mathrm{a}^{*}$ and $\mathrm{b}^{*}$, which were different among cultivars. Regarding parameter $\mathrm{L}^{*}$, the brightest samples were 'Cherokee' and 'Xavante'. As for parameter a *, only Tupy cultivar differed from the others, presenting lower red color intensity compared to the other cultivars. As for parameter $\mathrm{b}^{*}$, Cherokee and Xavante cultivars presented the highest values, indicating lower blue color intensity (FIGURE 4).

However, the perception of color by our visual system is done in a three-dimensional way, and $\mathrm{L}^{*}, \mathrm{a}^{*}$ and $b^{*}$ values in isolation are not enough to predict the color of a sample (Nindo et al., 2003). Thus, for better understanding, the $\mathrm{L}^{*}$ values were plotted against the $\mathrm{b}^{*} / \mathrm{a}^{*}$ ratio, which indicates tonality (Hue) of the fruit (FIGURE 4).

Cultivars are different in color. 'Cherokee' fruits showed greater luminosity and higher red color intensity in relation to blue, and Tupy fruits showed lower luminosity and higher blue color intensity in relation to red (FIGURE 4). This difference in the tones of blue and red affects the perceived final fruit color, which can influence the purchase decision by consumers, since color indicates if the fruit presents or not ideal conditions for marketing and consumption (CECHI, 2003). In general, blackberry consumers have preference for uniformly colored fruits, with fully black and shiny fruits. (PIO and GONÇALVES, 2014).

The lowest $\mathrm{pH}$ values were found for Xavante and Guarani cultivars in the 2012/13 cycle and for Xavante in the 2013/14 cycle (TABLE 2). In contrast, 'Tupy' cultivar presented the highest $\mathrm{pH}$ in relation to the other cultivars in both cycles, reaching $\mathrm{pH}$ of 3.2 in 2012/13 and 3.3 in $2013 / 14$. When performing the chemical characterization of some blackberry varieties from Southern Brazil, Hirsch et al. (2012) found $\mathrm{pH}$ values ranging from 2.8 to 3.1, without significant differences among Tupy, Guarani and Cherokee cultivars. Croge et al. (2016) also found no significant differences among cultivars, with $\mathrm{pH}$ values ranging from 3.0 to 3.3 . Low $\mathrm{pH}$ values are required by the industry to increase food resistance to microbiological infections and to directly interfere with the processing conditions (FENNEMA, 2010). 
In relation to titratable acidity, the most acidic fruits were those of Xavante cultivar and the less acidic were those of 'Tupy' cultivar, and this parameter influences flavor, aroma, color and stability of fruits (CECCHI, 2003). Campagnolo and Pio (2012a) found no differences among Guarani, Xavante and Cherokee cultivar, with average acidity of $2.1 \%$ citric acid. However, Hirsch et al. (2012) verified that the percentages of citric acid in 'Tupy', 'Guarani' and 'Cherokee' cultivars were 1.6, 1.5 and 1.6, respectively. According to Mota (2006), this difference in fruit acidity, depending on the genotype, may be associated with the edaphoclimatic conditions of the crop. Furthermore, cultivars such as Xavante, are reported with predominantly more acidic flavor (CROGE et al., 2016).

Regarding soluble solids, the highest amount was found for the Cherokee cultivar in both productive cycles, which indicates that fruits are sweeter (TABLE 2). Antunes and Raseira (2004) reported soluble solids content for this cultivar at around 8 to $9{ }^{\circ} \mathrm{Brix}$ and characterized it as having good taste, tending to equilibrate. The same authors reported value of 8-10 ${ }^{\circ}$ Brix for 'Tupy' and 'Guarani' cultivars and $8{ }^{\circ}$ Brix for 'Xavante' cultivar. Croge et al. (2016) found values between 7.6 and 9.3 'Brix among cultivars, with 'Cherokee' being the sweetest cultivar. The content of soluble solids is influenced by a number of factors, such as soil type, fruit development time and application of cultivation techniques, such as fertilization and irrigation, and even in different production systems, Cherokee cultivar presented higher SS content (SEGANTINI et al., 2014; CROGE et al., 2016).

As for the TSS/TA ratio, it was observed that higher values and, consequently, better flavor, was obtained for Tupy cultivar. Campagnolo and Pio (2012a) also found better ratio for this cultivar, but the value found (5.6) was lower than that observed in the second production cycle. Croge et al. (2016) found the best taste for Cherokee cultivar, which reached the ratio of 10.1 in the 2013/14 cycle.

Figure 5 shows the average scores obtained for the sensory attributes of fruits. It was observed that judges showed greater acceptance for Tupy cultivar, which obtained higher scores for attributes global impression, appearance, texture and flavor. For the flavor attribute, no difference among cultivars was found.

The higher acceptance of 'Tupy' cultivar can be explained by the better relationship between acidity and soluble solids. In addition, 'Tupy' cultivar presented the largest fruits and a differentiated coloration compared to the others (FIGURE 4), which may have contributed to this result.

'Xavante' fruits obtained the lowest scores in relation to attributes global impression, appearance, firmness and flavor. The lowest titratable acidity / soluble solids ratio was observed for 'Xavante' fruits, which is directly related to lower acceptance. The texture value observed for 'Xavante' fruits was also smaller than the other cultivars, indicating that fruits have lower firmness, which is also not appreciated by consumers.

The fruit acceptability index is presented in Table 3 for the sensory attributes under study. Regarding appearance, texture and overall impression, fruits of Tupy, Guarani and Cherokee cultivars obtained acceptance greater than $70 \%$ and are considered fruits of good acceptance (DUTCOSKY, 2007).

For aroma attribute, there was no influence on the acceptance of cultivars, since several tasters emphasized that aroma was barely noticeable on samples. However, this attribute added to taste, constitutes attribute food flavor. Thus, it was observed that the taste of Tupy and Cherokee cultivars presented the greatest acceptance by judges, with no statistical difference from each other. 


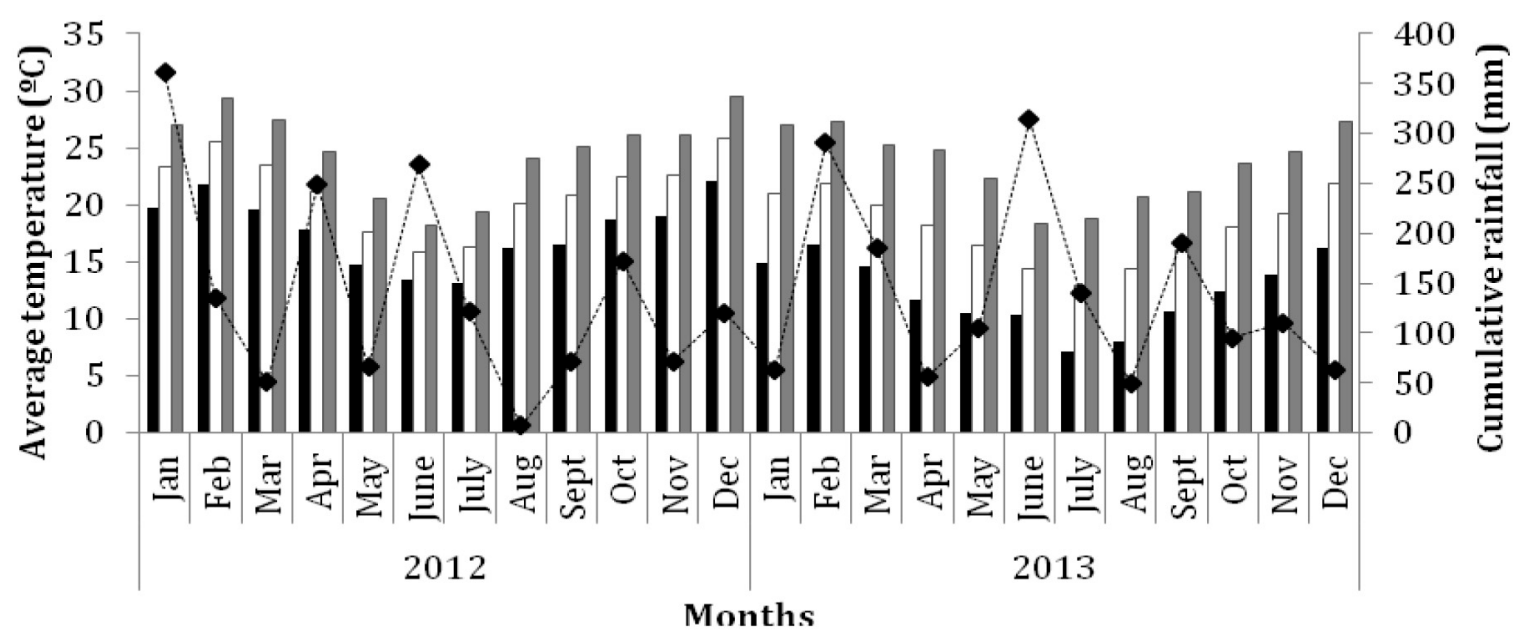

Figure 1. Monthly minimum, average and maximum temperatures $\left({ }^{\circ} \mathrm{C}\right)$ and cumulative rainfall (mm). Lapa-PR. (Minimum temperature $\square$; average temperature $\square$; maximum temperature $\square$; cumulative rainfall $-\bullet-$ ). Simepar (2012 and 2013).
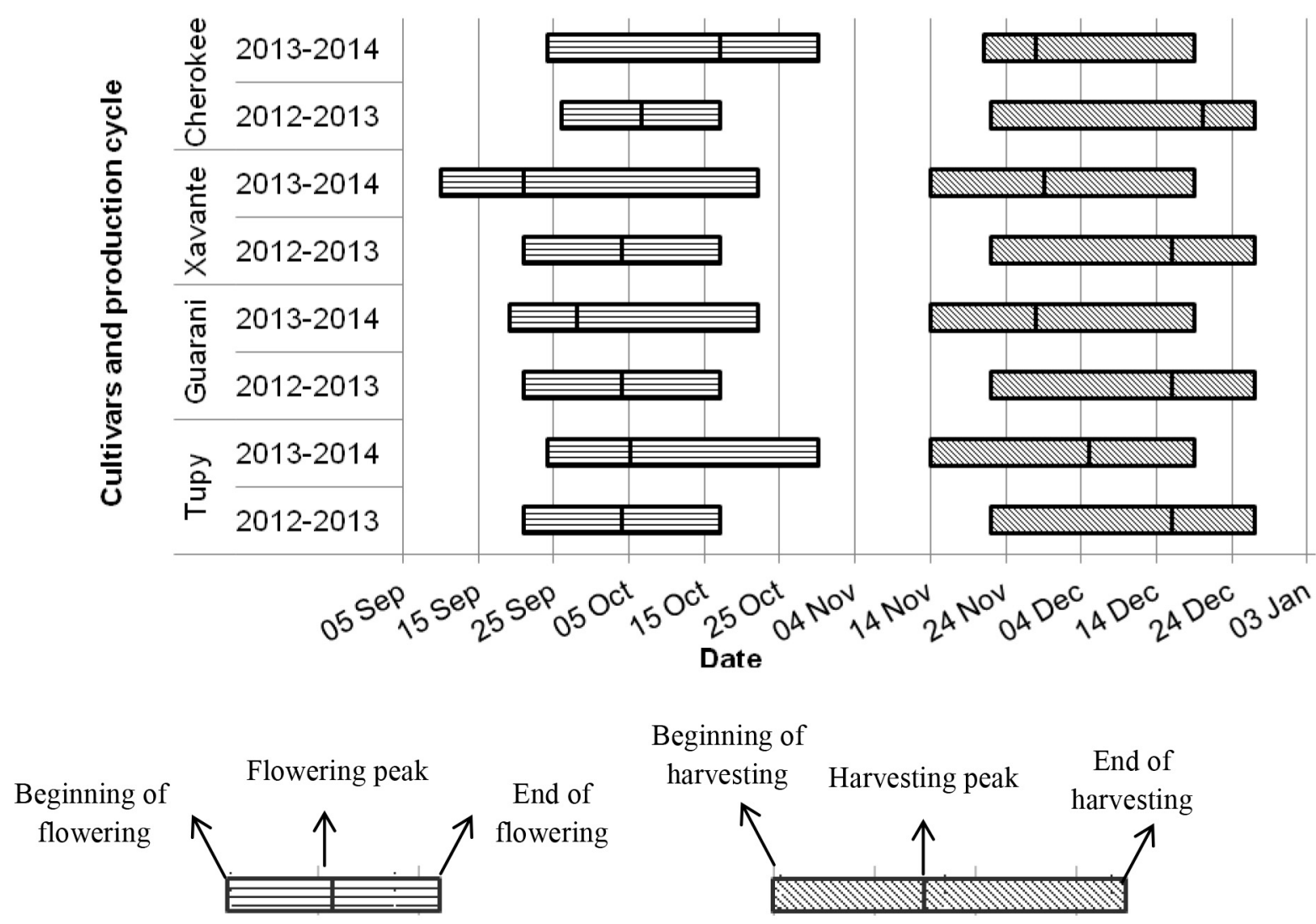

Figure 2. Flowering and harvesting period of blackberries in 2012/2013 and 2013/2014 cycles. 
Table 1. Production performance of blackberry cultivars in 2012/2013 and 2013/2014 cycles. Lapa-PR.

\begin{tabular}{ccccccc}
\hline & \multicolumn{2}{c}{ Production $\left(\right.$ Kg planta $\left.^{-1}\right)$} & \multicolumn{2}{c}{ Productivity $\left(\mathrm{t} \mathrm{ha}^{-1}\right)$} & \multicolumn{2}{c}{ Weight $\left(\mathrm{g} \mathrm{fruit}^{-1}\right)$} \\
\hline & $2012 / 13$ & $2013 / 14$ & $2012 / 13$ & $2013 / 14$ & $2012 / 13$ & $2013 / 14$ \\
\hline Tupy & $8.1 \mathrm{a}$ & $10.7 \mathrm{a}$ & $20.1 \mathrm{a}$ & $26.8 \mathrm{a}$ & $9.6 \mathrm{a}$ & $9.9 \mathrm{a}$ \\
Guarani & $3.7 \mathrm{~d}$ & $8.5 \mathrm{~b}$ & $9.2 \mathrm{~d}$ & $21.2 \mathrm{~b}$ & $5.5 \mathrm{~b}$ & $5.5 \mathrm{c}$ \\
Xavante & $6.2 \mathrm{~b}$ & $6.9 \mathrm{c}$ & $15.4 \mathrm{~b}$ & $17.4 \mathrm{c}$ & $6.8 \mathrm{~b}$ & $7.3 \mathrm{~b}$ \\
Cherokee & $4.6 \mathrm{c}$ & $5.4 \mathrm{~d}$ & $11.5 \mathrm{c}$ & $13.4 \mathrm{~d}$ & $6.3 \mathrm{~b}$ & $5.6 \mathrm{c}$ \\
\hline CV $(\%)$ & 15.96 & 16.84 & 15.96 & 16.84 & 9.19 & 6.58 \\
\hline
\end{tabular}

*Averages followed the same letter in column do not differ by Tukey test $p \leq 0.05$.

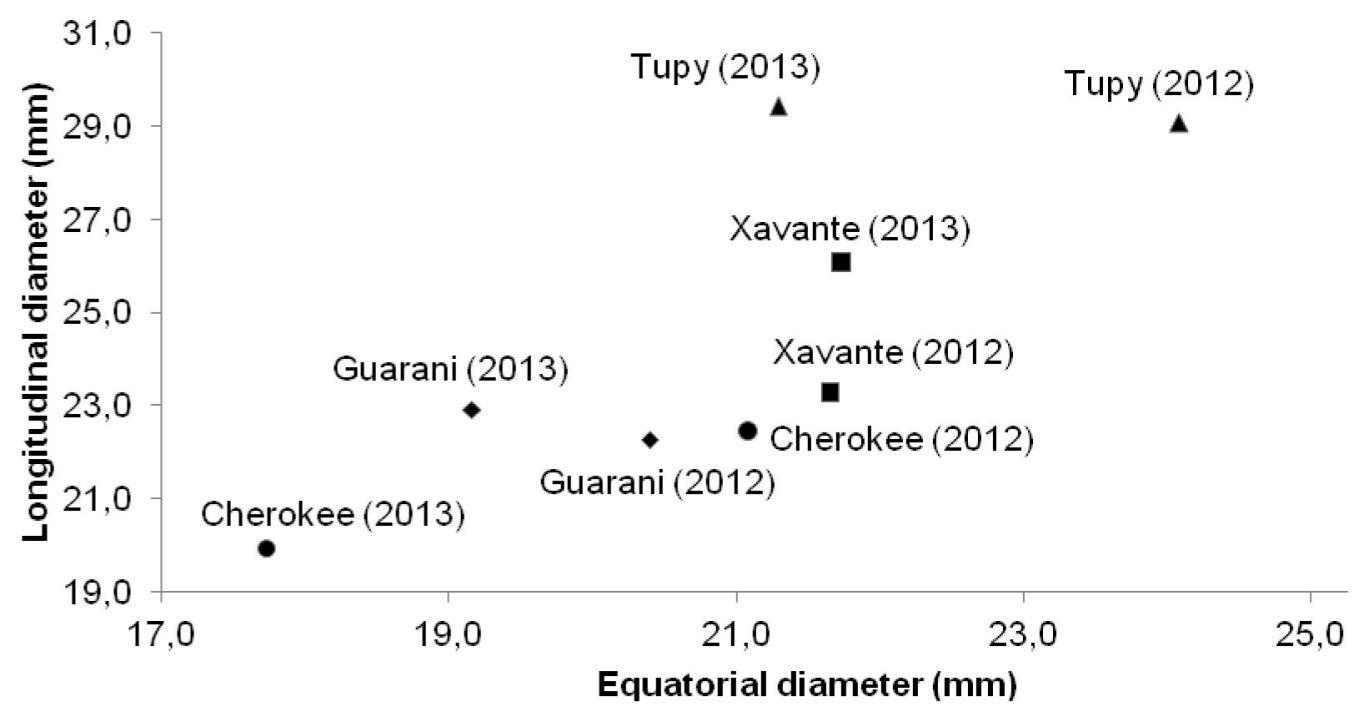

Figure 3. Average of equatorial and longitudinal diameter (mm) of blackberries in 2012/13 and 2013/14 cycles. Lapa-PR.

Table 2. Firmness, fruit color and chemical properties of blackberry fruits in 2012/2013 and 2013/2014 cycles. Lapa-PR.

\begin{tabular}{ccccccccccc}
\hline & $\begin{array}{c}\text { Firmness } \\
(\mathrm{N})\end{array}$ & \multicolumn{2}{c}{$\Delta \mathrm{E}^{\mathrm{ns}}$} & \multicolumn{2}{c}{$\mathrm{pH}$} & \multicolumn{2}{c}{$\begin{array}{c}\text { itratable acidity } \\
(\% \text { citric acid })\end{array}$} & $\begin{array}{c}\text { Soluble Solids } \\
\left({ }^{\circ} \text { Brix }\right)\end{array}$ & \multicolumn{2}{c}{$\begin{array}{c}\text { Ratio } \\
(\mathrm{SS} / \mathrm{TA})\end{array}$} \\
\hline & $2013 / 14$ & $2013 / 14$ & $2012 / 13$ & $2013 / 14$ & $2012 / 13$ & $2013 / 14$ & $2012 / 13$ & $2013 / 14$ & $2012 / 13$ & $2013 / 14$ \\
\hline Tupy & $0.4 \mathrm{~b}$ & 9.5 & $3.2 \mathrm{a}$ & $3.3 \mathrm{a}$ & $1.8 \mathrm{c}$ & $1.2 \mathrm{c}$ & $8.8 \mathrm{bc}$ & $7.4 \mathrm{bc}$ & $4.9 \mathrm{a}$ & $6.4 \mathrm{a}$ \\
Guarani & $0.7 \mathrm{a}$ & 9.6 & $3.0 \mathrm{c}$ & $3.0 \mathrm{~b}$ & $2.2 \mathrm{~b}$ & $1.3 \mathrm{ab}$ & $8.6 \mathrm{c}$ & $7.7 \mathrm{~b}$ & $3.9 \mathrm{c}$ & $5.7 \mathrm{c}$ \\
Xavante & $0.3 \mathrm{c}$ & 9.5 & $2.3 \mathrm{c}$ & $2.6 \mathrm{c}$ & $2.3 \mathrm{a}$ & $1.5 \mathrm{a}$ & $9.0 \mathrm{ab}$ & $6.9 \mathrm{c}$ & $3.9 \mathrm{c}$ & $4.6 \mathrm{~d}$ \\
Cherokee & $0.5 \mathrm{~b}$ & 9.2 & $3.1 \mathrm{~b}$ & $3.1 \mathrm{ab}$ & $2.1 \mathrm{~b}$ & $1.3 \mathrm{bc}$ & $9.2 \mathrm{a}$ & $8.3 \mathrm{a}$ & $4.3 \mathrm{~b}$ & $6.3 \mathrm{~b}$ \\
\hline $\mathrm{CV}(\%)$ & 11.32 & 13.87 & 7.12 & 6.10 & 11.71 & 9.81 & 9.43 & 6.40 & 10.45 & 7.33 \\
\hline
\end{tabular}

*Averages followed the same letter in column do not differ by Tukey test $p \leq 0.05$. Ns: not significant. 


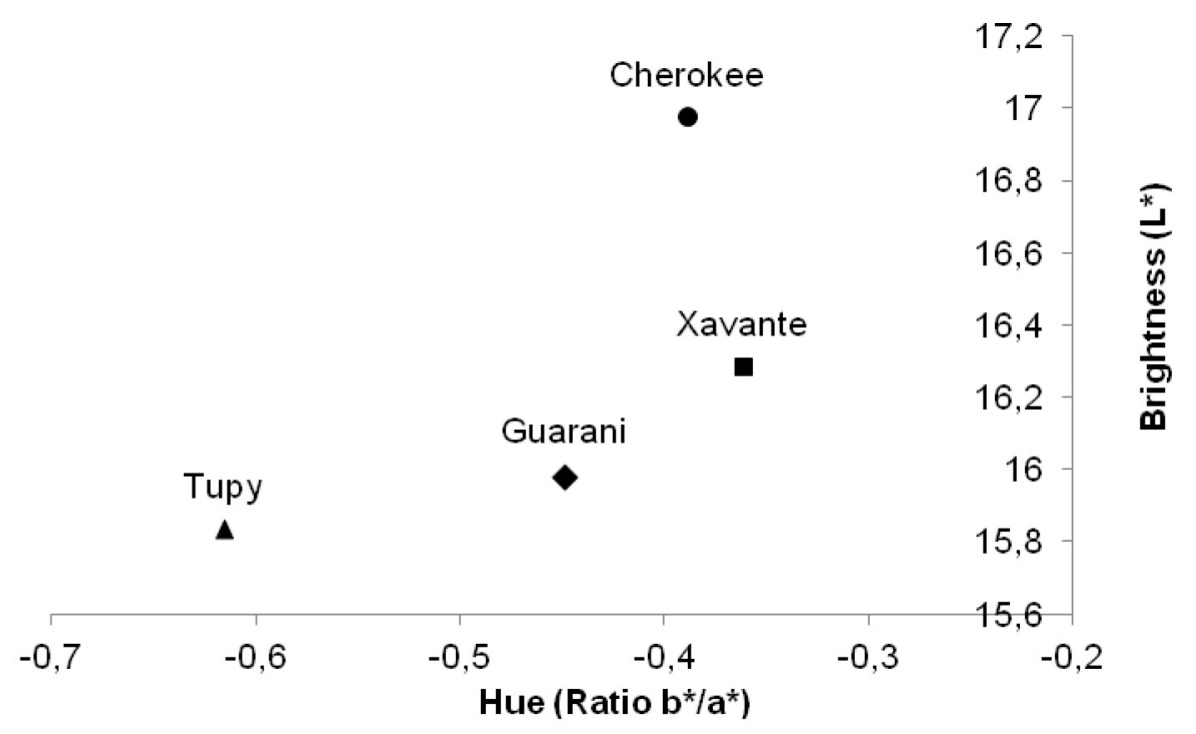

Figure 4. Hue and brightness values of blackberry fruits in 2013/2014. Lapa-PR.

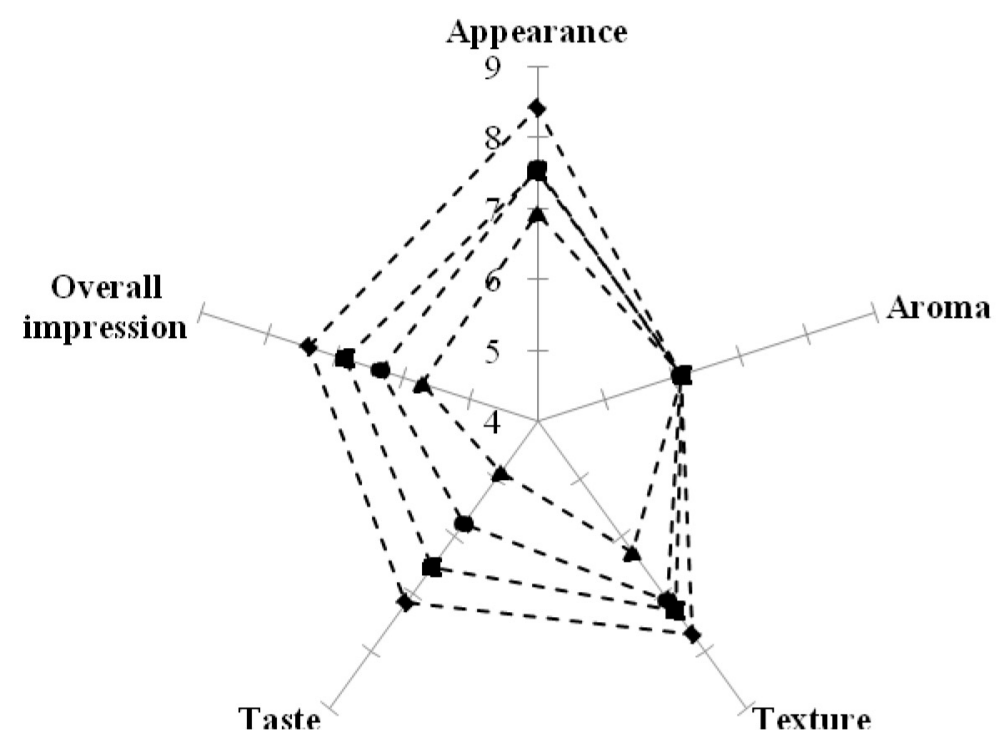

Figure 5. Average grades of the sensorial characteristics from acceptability test of the blackberries cultivars (Tupy; Guarani •; Xavante $\bullet$; Cherokee $\bullet$ ).

Table 3. Index of acceptability from blackberry cultivars.

\begin{tabular}{cccccc}
\hline & Appearance & Aroma $^{\text {ns }}$ & Texture & Taste & Overall impression \\
\hline Tupy & $93.5 \mathrm{a}$ & 68.0 & $85.6 \mathrm{a}$ & $79.6 \mathrm{a}$ & $82.1 \mathrm{a}$ \\
Guarani & $84.1 \mathrm{~b}$ & 67.9 & $79.2 \mathrm{~b}$ & $64.2 \mathrm{~b}$ & $70.5 \mathrm{c}$ \\
Xavante & $77.0 \mathrm{c}$ & 68.3 & $69.9 \mathrm{c}$ & $54.3 \mathrm{c}$ & $63.6 \mathrm{~d}$ \\
Cherokee & $83.6 \mathrm{~b}$ & 68.4 & $81.2 \mathrm{ab}$ & $72.7 \mathrm{a}$ & $76.1 \mathrm{~b}$ \\
\hline CV $(\%)$ & 17.27 & 22.26 & 19.74 & 22.39 & 21.90 \\
\hline
\end{tabular}

*Averages followed the same letter in column do not differ by Tukey test $p \leq 0.05$.Ns: not significant. 


\section{Conclusions}

Under the cultivation conditions of the present study, Tupy cultivar showed the best results in attributes production, average fruit quality and acceptable by consumers. scheduling.

Cultivars under study do not allow production

Only Xavante fruits should be indicated for processing.

\section{Acknowledgements}

This study was funded in part by the Coordenação de Aperfeiçoamento de Pessoal de Nível Superior - Brasil (CAPES) - Finance Code 001. To CNPq (National Council for Scientific and Technological Development) and to Araucária Foundation for supporting this research.

\section{References}

ALVES, G.; SILVA, J.; MIO, L. L. M.; BIASI, L. A. Comportamento fenológico e produtivo de cultivares de pessegueiro no Município da Lapa, Paraná. Pesquisa Agropecuária Brasileira, Brasília, v.47, p.1596-1604, 2012.

ANTUNES, L. E. C. Amora-preta: nova opção de cultivo no Brasil. Ciência Rural, Santa Maria, v. 32, n. 1, p. 151158, 2002.

ANTUNES, L. E. C.; GONÇALVES, E. D.; TREVISAN, R. Fenologia e produção de cultivares de amoreira-preta em sistema agroecológico. Ciência Rural, Santa Maria, v.40, n.9, p.1929-1933, 2010.

ANTUNES, L. E. C.; HOFFMANN, A. Pequenas frutas - O produtor pergunta, a Embrapa responde. 1.ed. Brasília, DF: Embrapa, 2012. 194 p.

ANTUNES, L. E. C.; PEREIRA, I. dos S.; PICOLOTTO, L.; VIGNOLO, G. K.; GONÇALVES, M. A. Produção de amoreira-preta no Brasil. Revista Brasileira de Fruticultura, Jaboticabal, v. 36, n. 1, p.100-111, 2014.

ANTUNES, L. E. C.; RASEIRA, M. C. B. Aspectos Técnicos da Cultura da Amora-preta. Pelotas: Embrapa Clima Temperado, 2004. 27 p.

ANTUNES, L.E.C. Blossom and ripening periods of blackberry varieties in Brazil. Journal American Pomological Society, University Park, v.54, n.4, p.164$168,2000$.
ASSOCIAÇÃO BRASILEIRA DE NORMAS TÉCNICAS. 1993. NBR 14140: alimentos e bebidas análise sensorial - teste de análise descritiva quantitativa (ADQ). Rio de Janeiro.

CAMPAGNOLO, M. A.; PIO, R. Produção de amoreirapreta 'Tupy' sob diferentes épocas de poda. Ciencia Rural, Santa Maria, v. 42, n. 3, p. 225-231, 2012a.

CAMPAGNOLO, M.A.; PIO, R. Phenological and yield performance of black and redberry cultivars in western Paraná state. Acta Scientiarum Agronomy, Maringá, v.34, p.439-444, 2012 b.

CECCHI, H. M. Fundamentos teóricos e práticos em análise de alimentos. 2.ed. rev. Campinas: Unicamp, 2003. $123 \mathrm{p}$.

CLARK, J. R.; FINN, C. E. Blackberry breeding and genetics. Fruit, vegetable and Cereal Science and Biotechnology, Ikebone, v. 5, n. 1, p. 27-43, 2011.

CROGE, C. P.; CUQUEL, F. L.; BIASI, L. A.; DE BONA, C. Performance of blackberry cultivars in Cerro Azul PR. Revista Brasileira de Fruticultura, Jaboticabal, v. 38, n.3, p. e-141, 2016.

CURI, P. N.; PIO, R.; MOURA, P. H. A.; TADEU, M. H.; NOGUEIRA, P. V.; PASQUAL, M. Produção de amora-preta e amora-vermelha em Lavras-MG. Ciência Rural, Santa Maria, v. 45, n.8, p.1368-1374, 2015.

DUTCOSKY, S. D. Análise Sensorial de Alimentos. 2.ed. rev. e ampl. Curitiba: Champagnat, 2007. 238 p.

FENNEMA, O. R.; DAMODARAN, S.; PARKIN, K. Fennema's Food Chemistry. $4^{\mathrm{a}}$ ed., Artmed, 2010. 900 p.

GUEDES, M.N.S.; ABREU, C.M.P.; MARO, L.A.C.; PIO, R.; ABREU, J.R.; OLIVEIRA, J.O. Chemical characterization and mineral levels in the fruits of blackberry cultivars grown in a tropical climate at an elevation. Acta Scientiarum Agronomy, Maringá, v.35, n.2, p.191-196, 2013.

HIRSCHI, G. E.; FACCO, E. M. P.; RODRIGUES, D. B.; VIZZOTTO, M.; EMANUELLI, T. Caracterização físico-química de variedades de amora-preta da região sul do Brasil. Ciência Rural, Santa Maria, v. 42, n. 5, p. 942-947, 2012.

INSTITUTO ADOLFO LUTZ. Métodos físico-químicos para análise dos alimentos. 4.ed. Brasília, DF: Ministério da Saúde, 2005. 1115 p. 
MOTA, R. V. Caracterização do suco de amora-preta elaborado em extrator caseiro. Ciência e Tecnologia de Alimentos, Campinas, v. 26, n. 2, p. 303-308, 2006.

NINDO, C. I.; SUN, T.; WANG, S.W.; TANG, J.; POWERS, J.R. Evaluation of drying technologies for retention of physical quality and antioxidants in asparagus (Asparagus officinalis, L.). Society of Food Science and Technology, Washington, v. 36, p. 507-516, 2003.

OLIVEIRA, D. M.; ROSA, C. I. L. F.; KWIATKOWSKI, A.; CLEMENTE, E. Biodegradable coatings on the postharvest of blackberry stored under refrigeration. Revista Ciência Agronômica, Ceará, v. 44, n. 2, p. 302309, 2013.

PEREIRA, I. DOS S.; PICOLOTTO, L.; CORREA, A. P. A.; RASEIRA, M. do C. B.; ANTUNES, L. E. C. Informações técnicas de cultivares de amoreira-preta. Embrapa Clima Temperado, 2014.

PEREIRA, I. S.; PICOLOTTO, L.; GONÇALVES, M. A.; VIGNOLO, G. K.; ANTUNES, L. E. C. Potassium fertilization affects floricane mineral nutrient content, growth, and yield of blackberry grown in Brazil. HortScience, Alexandria, v. 50, n.8, p.1234-1240, 2015.

PIO, R; GONÇALVES, E. D. Cultivo da amoreira preta. In: PIO, R. Cultivo de fruteiras de clima temperado em regiões subtropicais e tropicais. 1.ed. Lavras: MG, 2014. p. $186-221$.

POLING, E.B. Blackberries. Journal of Small Fruit and Viticulture, Binghamton, v.14, n.1-2, p.38-69, 1996.
REYES-CARMONA, J.; YOUSEF, G. G.; MARTINEZPENICHE, R. A.; LILA, M. A. Antioxidant Capacity of Fruit Extracts of Blackberry (Rubus sp.) Produced in Different Climatic Regions. Journal of Food science, Chicago, v. 70, p. 497-503, 2005.

SCALZO, J. BATTINO, M. COSTANTINI, E. MEZZETTI, B. Breeding and biotechnology for improving berry nutritional quality. Biofactors, Amsterdam, v. 23, n. 4, p. 213-220, 2005.

SEGANTINI, D. M.; LEONEL, S.; CUNHA, A. R.; FERRAZ, R. A.; RIPARDO, A. K. S. Exigência térmica e produtividade da amoreira-preta em função das épocas de poda. Revista Brasileira de Fruticultura, Jaboticabal, v. 36, n. 3, p. 568- 575, 2014.

SILVA, R.P. da; DANTAS, G.G.; NAVES, R.V.; CUNHA, M.G. Comportamento fenológico de videira, cultivar Patrícia em diferentes épocas de poda de frutificação em Goiás. Bragantia, v.65, p.399-406, 2006.

SOUZA, A. V.; RODRIGUES, R. J.; GOMES, E. P.; GOMES, G. P.; VIEITES, R. L. Caracterização bromatológica de frutos e geleias de amora-preta. Revista Brasileira de Fruticultura, Jaboticabal, v. 37, n.1, p.013-019, 2015.

STRIK, B. Worldwide production of blackberries. Acta Horticulturae, Leuven, n. 777, p. 209-218, 2008.

ZIELINSKI, A. A. F.; GOLTZ, C.; YAMATO, M. A. C.; ÁVILA, S.; HIROOKA, E. Y.; WOSIACKI, G.; NOGUEIRA, A. DEMIATE, I. M. Blackberry (Rubus spp.): influence of ripening and processing on levels of phenolic compounds and antioxidant activity of the 'Brazos' and 'Tupy' varieties grown in Brazil. Ciência Rural, Santa Maria, v. 45, n.4, p.744-749, 2015. 